марского научного центра РАН. 2018. Т. 20, № 3. C. 208-214.

31. Лычагина Е.Л. Поздний неолит Пермского Предуралья (к вопросу о соотношении памятников с накольчатой и гребенчатой керамикой): автореф. дис. ... канд. ист. наук. Казань, 2004. 24 с.

32. Кондратьев С.А., Шалапинин А.А. К проблеме хронологического соотношения комплексов позднего неолита-энеолита лесной зоны Среднего По- волжья // Известия Самарского научного центра РАН. 2011. T. 13, № 3. С. 259-263.

33. Сидоров В.В., Энговатова А.В. Протоволосовский этап или культура? // Тверской археологический сборник. Вып. 2. Тверь: ТГОМ, 1996. С. 164-182.

Статья публикуется при поддержке грантов РФФИ № 18-39-00059 «Ранние гончарные традиции населения Среднего Предуралья" и № 18-0900040.

\title{
NOVOILYINSKAYA POST-NEOLITHIC CULTURE IN THE MIDDLE AND UPPER KAMA RIVER REGION
}

(C) 2019

\author{
Lychagina Evgeniya Leonidovna, candidate of historical sciences, \\ associate professor of Domestic and World History, Archeology Department \\ Perm State Humanitarian Pedagogical University (Perm, Russian Federation) \\ Vybornov Alexander Alekseevich, doctor of historical sciences, professor, \\ head of Domestic History and Archeology Department \\ Samara State University of Social Sciences and Education (Samara, Russian Federation) \\ Zhukova Olga Vladimirovna, curator \\ Perm Local History Museum (Perm, Russian Federation)
}

Abstract. This paper deals with the analysis of the materials from the Novoilyinskaya culture monuments in the Middle Kama River region, traces the issue history and determines how much is known about it. The main sources of the issue are given and their reliability is determined here. The location of the sites and the characteristic parameters of dwellings are recorded. Their similarity with the Neolithic is stated. The ceramic and stone tools are described. The characteristic and special features are distinguished. A comparative analysis of the complexes with the materials of the late Neolithic is carried out, that reveals a certain similarity. The paper considers the issue of the metalwork residues presence at the Novoilyinskaya culture monuments. It is concluded that there is no evidence of the Eneolithic character of the Novoilyinskaya culture sites. The database on radiocarbon chronology of the Novoilyinskaya culture complexes is analyzed. The most valid values are highlighted. Their chronological interval of existence is determined: 5200-4500 BP. The issue of the genesis of the Novoilyinskaya culture in the Middle Kama River region is covered. The proximity with the culture of the local Neolithic is stated, as well as the role of cultures of adjacent territories is assumed. A comparative analysis with materials of the Krasnomostovsky type of the forest Middle Volga region is given. The conclusion about their chronological correlation is made. The authors also come to the conclusion about the Post-Neolithic age of the Novoilyinskaya culture. This culture is included in the range of the forest Middle and Upper Volga region cultures.

Keywords: Novoilyinskaya culture; Middle Kama River region; Upper Kama River region; monuments; dwellings; pottery; comb imprint; stone tools; metalwork; technological analysis of pottery; radiocarbon dates; chronology; forest Middle Volga region; Krasnomostovsky type; Post-Neolithic.

УДК 902.6

DOI 10.24411/2309-4370-2019-12214

Статья поступила в редакцию 01.02.2019

\section{НОВОИЛЬИНСКИЕ ПАМЯТНИКИ НИЖНЕГО ПРИКАМЬЯ: СОВРЕМЕННОЕ СОСТОЯНИЕ ПРОБЛЕМЫ}

(C) 2019

\author{
Морозов Виктор Владимирович, аспирант отдела первобытной археологии \\ Институт археологии им. А.Х. Халикова Академии наук Республики Татарстан \\ (2. Казань, Российская Федераџия)
}

\begin{abstract}
Аннотащия. В статье анализируются памятники новоильинской культуры Нижнего Прикамья, которые функционировали после распада камской неолитической культуры и до появления в регионе энеолитических культур с пористой (раковинной) керамикой. Анализ керамического комплекса новоильинской культуры позволяет утверждать, что по ряду показателей эта посуда близка гребенчатой керамике камской культуры. Отсутствие четких данных по стратиграфии и планиграфии, небольшая серия абсолютных дат не дают четкого представления о времени формирования и развития новоильинской культуры. Имеющиеся в настоящее время данные позволяют утверждать, что к последней четверти V тыс. cal BC самарские воротничковые (ивановские) традиции исчезают. В Нижнем Прикамье сформировывается специфичная керамика «неолитоидного» облика. При этом на новоильинской керамике Икско-Бельского междуречья фиксируются особенности, которые являются левшинскими реминисценциями, не характерными для Среднего и Верхнего Прикамья, это - наплывы с внутренней стороны венчика, ряды ямочно-жемчужных вдавлений под венчиком, закрытые формы посуды и орнамент «шагающая гребенка». Близость керамических комплексов новоильинских памятников с поздненеолитической керамикой камской культуры, наличие радиоуглеродных дат, от-
\end{abstract}


сутствие признаков металлообработки доказывают, что функционирование новоильинских памятников в Нижнем Прикамье происходило на границе каменного века и эры ранних металлов. Другим немаловажным моментом остается вопрос о том, какие именно южные компоненты приняли участие или оказали воздействие на формирование новоильинского типа. Исследователи лесостепных энеолитических культур высказывали предположения, что в становлении лесных культур меднокаменного века - гаринской, борской и средневолжского варианта волосовской культур - принимали участие токские и даже алтатинские элементы. По нашему мнению, влияние токских традиций отчетливо фиксируется уже на новоильинской керамике. Такие выводы подкрепляются датами по ${ }^{14} \mathrm{C}$, устанавливающими синхронность токских и новоильинских памятников.

Ключевые слова: новоильинская культура; токский тип; неолит; энеолит; Нижнее Прикамье; ИкскоБельское междуречье; лес; лесостепь; поселение; керамика; шамот; комплексы пористой (раковинной керамики); культурная диффузия; левшинские реминисценции; типологическая близость; многокомпонентное воздействие.

\section{Введение}

Своеобразный керамический материал, выявленный на памятниках Среднего Прикамья, позволил О.Н. Бадеру рассмотреть вопрос о выделении нового культурного типа керамики, названного исследователем «флажковым». На основе стратиграфии изученных поселений О.Н. Бадер датировал «флажковую» керамику поздними этапами (борский этап) турбинской (гаринско-борской) культуры [1, с. 125].

Материалы новых раскопок в зоне строительства Воткинской ГЭС позволили расширить границы распространения подобной керамики, которая в конечном счете была объединена в рамках новоильинской культуры [2, с. 60-74].

Позднее материалы новоильинской культуры были выявлены на всем протяжении р. Кама и ее притоков [3, с. $40-66 ; 4$, с. $70-95 ; 5$, с. 3-18; 6, с. 3-21].

Огромную работу в систематизации и осмыслении новоильинских древностей провел Л.А. Наговицын [7-10]. К началу 90-х гг. ХХ в. он отмечал, что среди исследователей данной культуры нет единства по ее хронологической позиции и характерным особенностям вообще, составляющим ее специфику [10, с. 60]. В отличие от О.Н. Бадера [1], Л.А. Наговицын обосновывал иную хронологическую схему, где новоильинской культуре отводилось пространство между поздним камским неолитом и поздним энеолитом (гаринско-борской культуры). В новоильинскую культуру, как локальный вариант, им были включены керамические материалы красномостовского типа [10, c. 70], открытые и изученные на поселенческих памятниках Марийского Поволжья В.В. Никитиным $[11$, c. $31-43 ; 12$, c. $41-51]$.

С появлением радиоуглеродных датировок было уточнено место новоильинских древностей на абсолютной хронологической шкале. Ранние памятники новоильинской культуры были синхронизированы с поздним неолитом региона, а поздние - с памятниками гаринской культуры, тем самым гипотеза Л.А. Наговицына была подтверждена естественнонаучными методами [13, с. 35].

Радиокарбонным методом было установлено, что новоильинская керамика датируется от последней четверти V тыс. calBC до конца IV тыс. cal BC [13]. Такой длительный (более тысячи лет) промежуток функционирования переходных памятников от неолита к эре ранних металлов ставится в настоящее время под сомнение [14-16] и валидными признаются наиболее древние даты, которые соприкасаются с финалом неолитических древностей камской культуры.

Таким образом, за 40-летний период изучения новоильинских древностей определилось место данной культуры в системе неолита - энеолита Прикамья, был накоплен обширный источниковый фонд, характе- ризующий материальную культуру населения, функционировавшего во временном промежутке с концом функционирования камской культуры и до появления пористой (раковинной) керамики в Прикамье.

Данная статья посвящена анализу материальной культуры (керамики) новоильинских памятников Нижнего Прикамья.

\section{Керамические комплексы Новоильинской}

культуры в Нижнем Прикамье

K концу V тыс. до н.э. (4200 calBC) заканчивается распад (или трансформация) камской неолитической культуры. Этот процесс, скорее всего, начинается раньше - в середине тысячелетия, когда появляются первые культурные контакты населения Нижнего Прикамья с восточным ареалом Мариупольской КИО. При переходе от развитого к заключительному этапу камской культуры на ее материалах отчетливо фиксируются южные элементы, такие как характерная каменная индустрия (крупные пластины) и появление своеобразной керамики. Трансформация камской культуры носила не мгновенный характер и, видимо, занимала значительный промежуток времени в несколько сотен лет.

Результаты радиоуглеродного датирования различных образцов керамики позволяют утверждать, что к 4200 cal BC $[17 ; 13]$ на керамике Нижнего Прикамья (рис. 1) пропадают воротничковые утолщения с внешней стороны венчика. Керамическая посуда возвращается к истокам - приобретает неолитоидный облик (полуяйцевидная закрытая форма сосудов, сплошное украшение орнаментом внешней поверхности сосудов). Все чужеродные элементы на керамике, связанные с самарской культурой (ивановский тип), изживают себя. В конце третьей четверти V тыс. до н.э. на территории Нижнего Прикамья появляются комплексы глиняной посуды новоильинского культуры.

Наиболее информативными являются поселения Икско-Бельского междуречья (восточная часть Нижнего Прикамья) изученные большими площадями. Всего здесь учтено шесть стоянок и поселений: Дубовогривская II [18; 19], Русско-Азибейская [20], Татарско-Азибейское II [21], Игимская [22; 23; 19], Сауз I-II $[6 ; 24 ; 25]$. В эту группу можно отнести материалы Старонагаевского могильника [26-28]. И один памятник, тяготеющий к Южному Предуралью, - Давлекановское поселение [29].

Дубовогривская II стоянка располагалась на северо-восточной окраине бывшей деревни Дубовая грива Челнинского района Татарской АССР (ныне остров Дубовая грива на Нижнекамском водохранилище, Тукаевский район РТ), на северном склоне песчаной дюны, возвышающийся над поймой на 4,5 м. Памятник выявлен разведкой КФАН СССР ле- 
Морозов В.В.

Новоильинские памятники Нижнего Прикамья: современное состояние.

07.00.00 - исторические науки и археология

том 1964 г. под руководством П.Н. Старостина. Тогда исследователи обратили внимание на западины, расположенные компактной группой. Заложенный шурф в центре одной из них выявил наличие культурного слоя, фрагменты толстостенных сосудов и кремневые сколы, после чего шурф был рекультивирован $[18$, с. 34$]$.

В 1969 г. на месте котлованов были заложены раскопы (раскопы I-III, V), давшие в значительном количестве материалы эпохи поздней бронзы, результаты этих работ были введены в научный оборот $[30$, с. 109-120]. Во время работы экспедиции Р.С. Габяшевым на заброшенных огородах была найдена неолитическая керамика. Аналогичная посуда была встречена в раскопах II и V, что позволило исследователям сделать вывод о функционировании на территории стоянки неолитического поселения $[18$, c. 36$]$. С целью выявления границы стоянки позднего каменного века была заложена сетка шурфов, позволившая определить приблизительные размеры неолитического поселения, которые достигали 20 тыс. м $^{2}[18$, с. 36]. В центральной части поселения, на расстоянии 80 м друг от друга, были заложены раскопы (IV, VI), результаты исследования которых большей частью не опубликованы или введены в научный оборот частично [31].

Первоначальная интерпретация керамического материала стоянки, сводилась к тому, что разнотипная гребенчатая керамика отображала хронологические этапы внутри камской культуры. Выделенный впоследствии новоильинский (гагарский) тип керамики на Каме $[1 ; 2]$ и красномостовский на Средней Волге $[11 ; 12]$, позволил по-новому освятить часть гребенчатых материалов Дубовогривской II стоянки $[32$, с. 50, 54], выделив среди всего пласта неолитической керамики «флажковый» тип, который был синхронизирован с эрой ранних металлов.

Изученная нами керамическая коллекция с памятника позволила в предварительном плане установить соотношение новоильинских древностей и гребенчатой керамики камкой культуры. Всего по бесспорно различающимся венчикам было учтено 27 сосудов, интерпретированных как новоильинские. Их отличия от левшинской керамики камской культуры следующие: форма посуды (слегка открытая или с прямым горлом, переходящим в раздутое тулово), срез венчика (приостренный, прямой и слегка сужающийся), орнамент (короткий гребенчатый оттиск, как правило, крупный), разреженные пространства между зонами орнамента, ямчатые вдавления (в одном случае) (рис. 2).

Планиграфическое распределение керамики новоильинской культуры на Дубовогривской II стоянке показало, что скопления и развалы такой посуды концентрировались в южной части раскопа VI и небольшими скоплениями в других раскопах. Стратиграфические наблюдения, несмотря на сильную перемешанность культурного слоя, показывают, что основные развалы и скопления новоильинской посуды залегают выше, чем накольчатая керамика, вместе с гребенчатой камской и воротничковой, и над ними, в слое, в котором помимо новоильинской, выделено девять сосудов с раковинной примесью в тесте гаринской энеолитической культуры и около 150 фрагментов керамики позднего бронзового и раннего железного веков [23, с. 102-105].

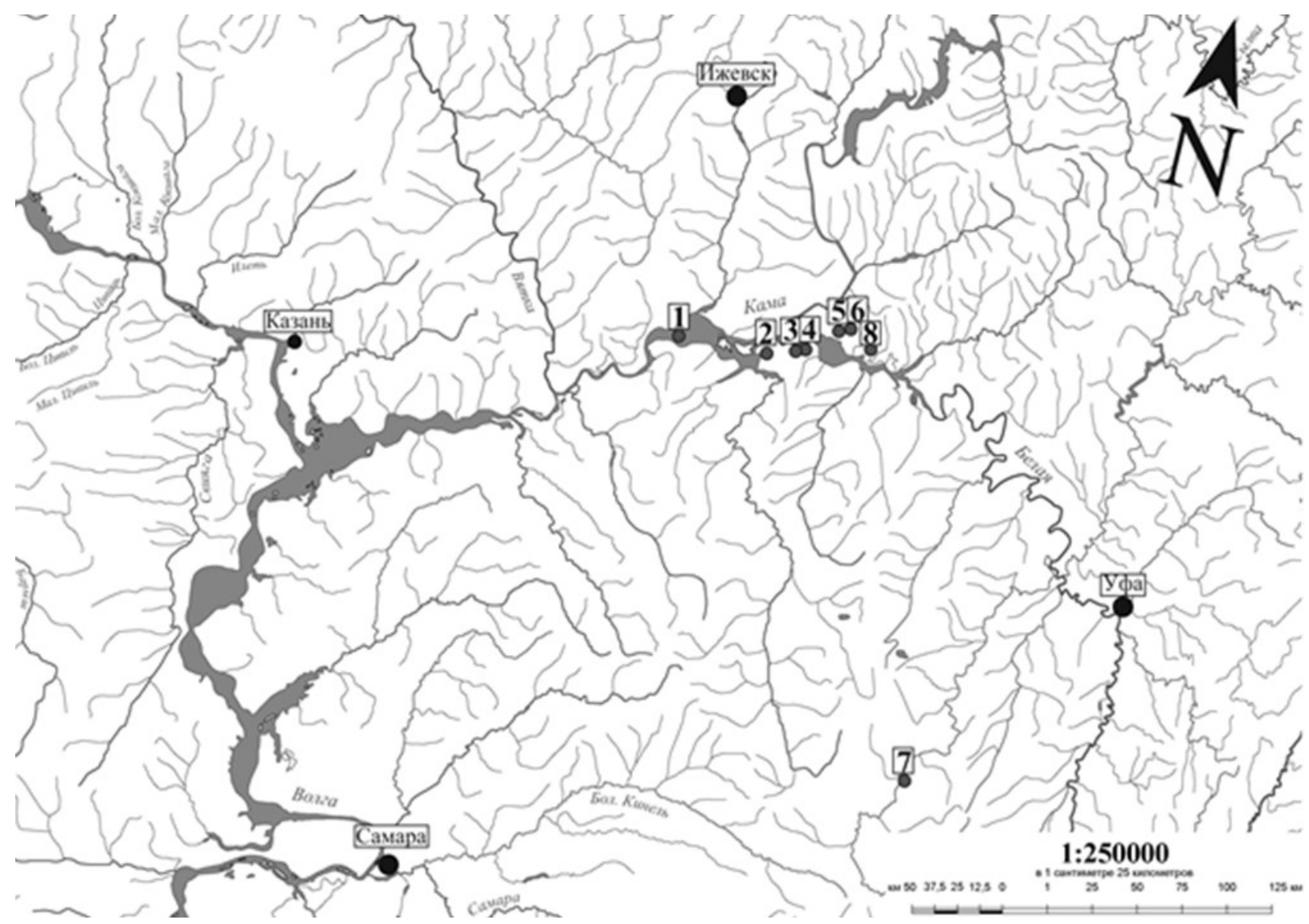

Рисунок 1 - Опорные памятники Новоильинской культуры Нижнего Прикамья.

1 - Дубовогривская II стоянка; 2- Игимская стоянка; 3- Русско-Азибейская стоянка; 4- Татарско-Азибейское II поселение; 5 - Поселение Сауз II; 6- Стоянка Сауз II; 7- Давлекановское поселение; 8-Старо-Нагаевский могильник 

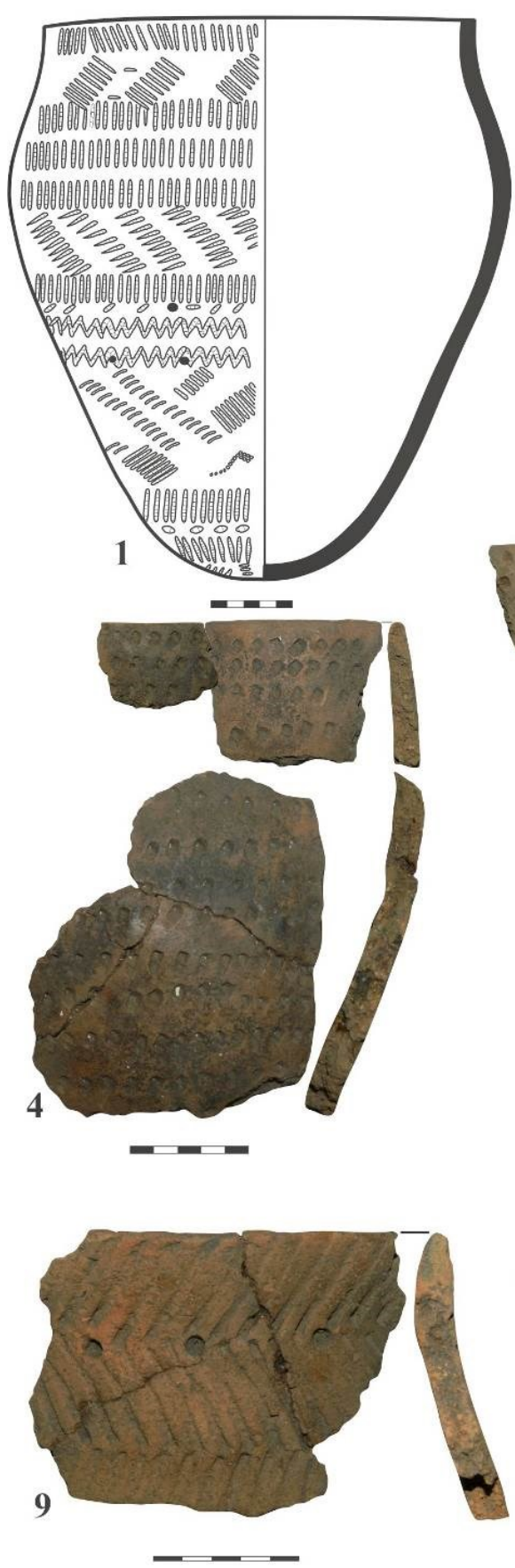
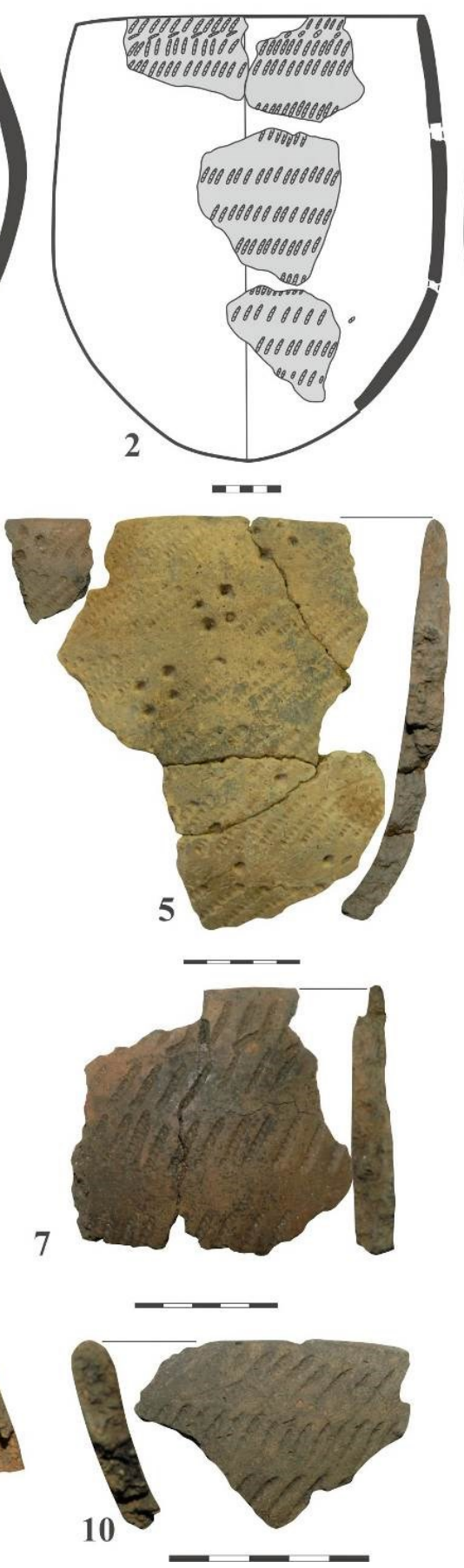

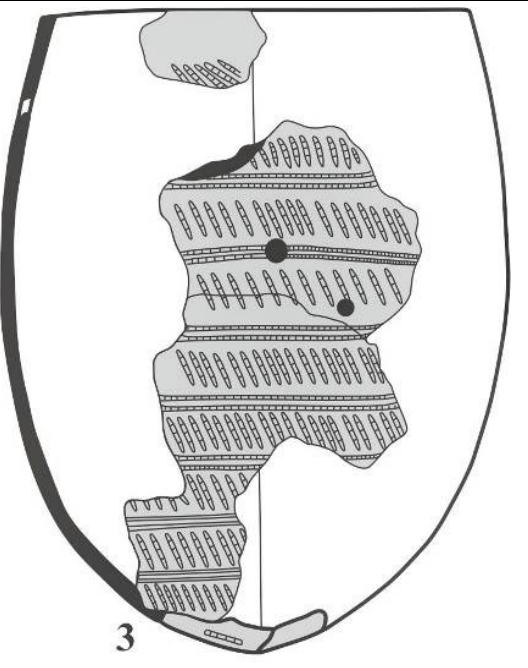

$=-1$

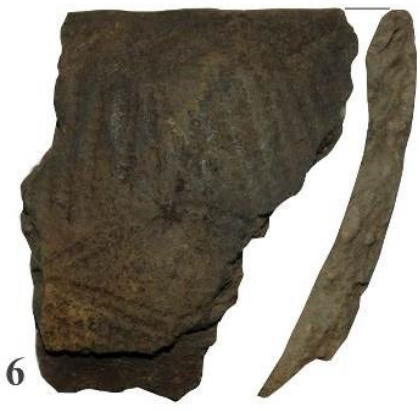

$-\cdots$

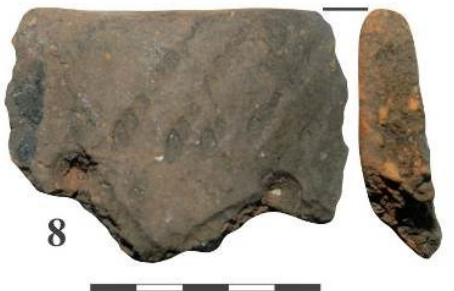

11

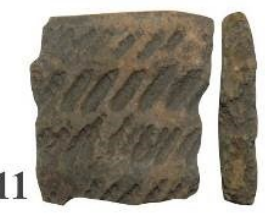

Рисунок 2 - Керамика Дубовогривской II стоянки. 1-3 - Реконструкция по Р.С. Габяшеву, П.Н. Старостину [18]

Изимская стоянка располагалась в 2 км к северу от с. Игим Мензелинского района РТ (ныне несуществующего), на высоком мысу первой и второй нерасчлененной террасы крупных рек у небольшого озера, являющегося продолжением Игимского озера [23]. Памятник открыт А.Х. Халиковым в 1958 г. [22]. На данный момент стоянка расположена в системе подтопленных водохранилищем старичных озер у безымянной протоки, соединяющей Каму и Ик. Мысовидный участок террасы сейчас занят лесом.

Всего на памятнике семью раскопами вскрыто

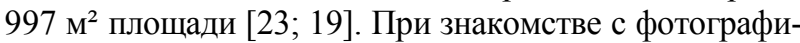
ями коллекции Игимской стоянки (выражаю благодарность Голубевой Екатерине) была выявлена обширная серия керамики, несомненно, новоильинского облика, происходящая из шестого и седьмого раскопов.

Сосуды толстостенные со средним значением 0,9-1,1 см. В тесте примесь шамота. В единичных случаях к шамоту, видимо, добавлялись органические примеси, о чем говорят редкие пустоты в глиняном тесте. Форма сосудов открытая, прямостенная и закрытой формы. Венчики округлые, скошенные во внутреннюю сторону и утонченные. Орнамент нанесен среднезубым и крупнозубым орнаментиром на всю внешнюю поверхность посуды, но в некоторых случаях со свободными зонами и некоторой небрежностью. Из элементов орнамента отмечены: «флажки», наклонные линии, горизонтальные ряды ямчатых вдавлений, зигзаги (рис. 3).

На Игимской стоянке новоильинская керамика типологически не выделялась. Судя по полевым описям, она залегала совместно с гребенчатой керамикой камской культуры. Стоит отметить, что на стоянке присутствует также внушительная серия борской и гаринской керамики. 

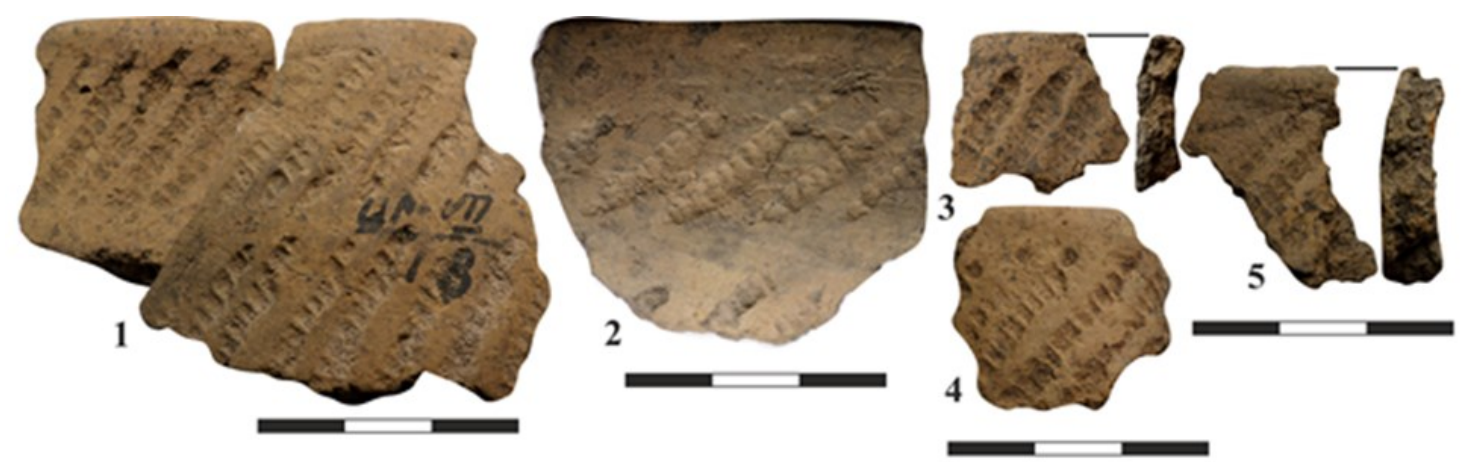

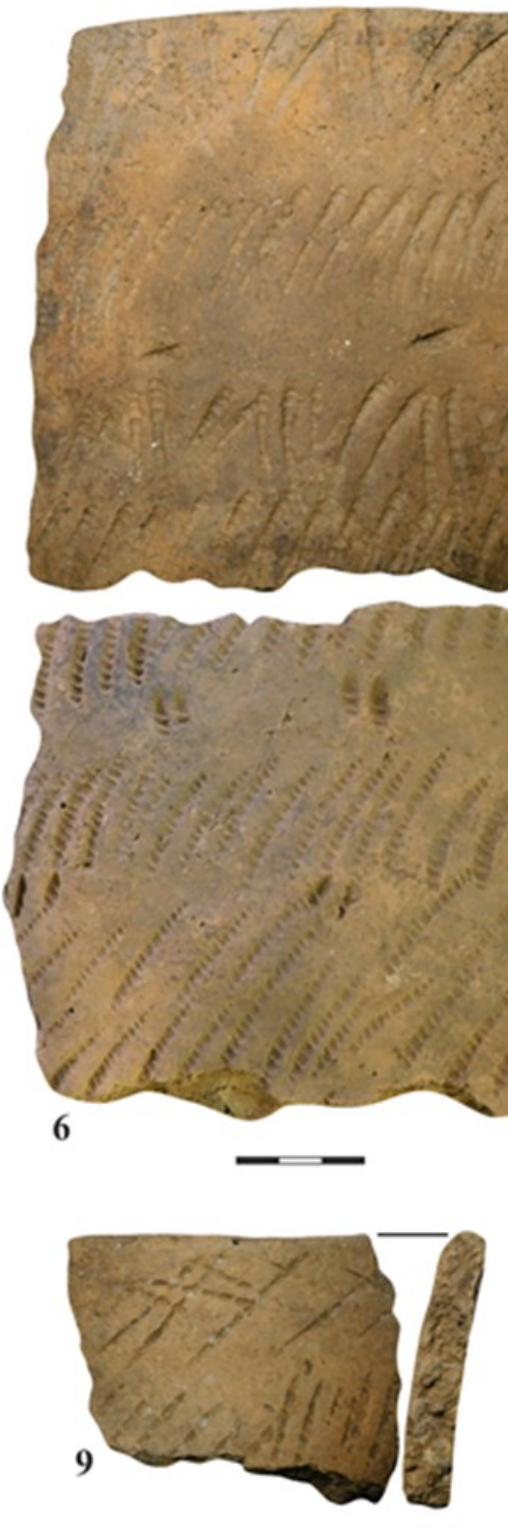

Рисунок 3 - Новоильинская керамика Игимской стоянки. 1-11-Образцы с Игимской стоянки
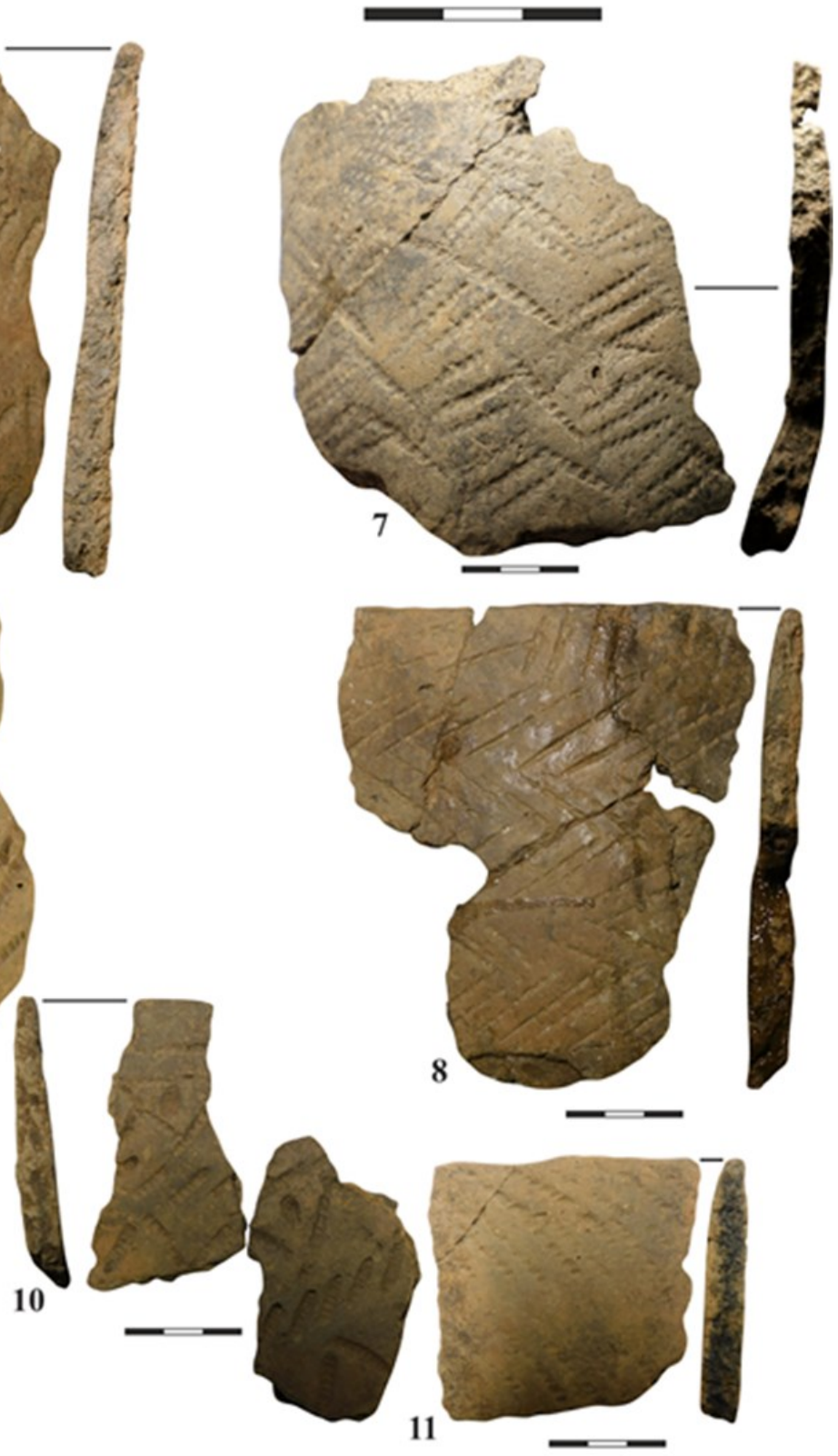

Русско-Азибейская стоянка, выявлена В.Ф. Генингом в 1958 г. [33]. В 1964 г. собран значительный подъемный материал, и в период 1970-1972 гг. на памятнике были проведены масштабные стационарные полевые исследования. Пятью раскопами было

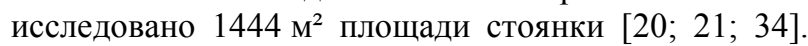
Позднее материалы третьего раскопа были опубликованы Р.С. Габяшевым, как происходящие из Русско-Азибейской III стоянки [35]. В 2005 г. Азибейские стоянки были осмотрены М.Ш. Галимовой, которая сделала вывод, что комплекс разновременных стоянок - Татарско-Азибейская III, Русско-Азибейс- кая, Русско-Азибейская III располагаются на одной и той же дюне и могут считаться одним многослойным памятником [36, с. 8].

Р.С. Габяшевым по материалам третьего раскопа к «флажковому» типу (новоильинской культуре) было отнесено 895 фр. керамики [35, с. 15]. Ее характеристика такова: сосуды толстостенные с примесями шамота и органических остатков. Преобладают сосуды крупных размеров с прикрытым горлом. Единично отмечены экземпляры с прямым горлом и намеченными плечиками. Венчики скошены вовнутрь и иногда с наплывом, округлые. Орнамент нанесен 
крупнозубым инструментом и состоит из горизонтальных рядов наклонного штампа. Сюда же отнесены сосуды, украшенные мелкозубчатым штампом в виде прямых, изогнутых линий и овальных отпечатков с орнаментальными мотивами в виде вертикальных и наклонных линий штампа, чередующихся с одинарным или двойным коротким зигзагом [35, с. 15-16].

Новоильинская керамика (рис. 4) третьего раскопа Русско-Азибейской стоянки была объединена в единый хронологический комплекс с накольчатой посудой и керамикой с «насечками». Р.С. Габяшев объясняет это стратиграфической нерасчлененностью данных групп керамики и их типологической близостью [35, с. 17].

Данные, полученные нами после обработки коллекции Русско-Азибейской стоянки, в том числе и с третьего раскопа (Русско-Азибейской III стоянки), позволяют не согласиться с некоторыми заключениями Р.С. Габяшева.
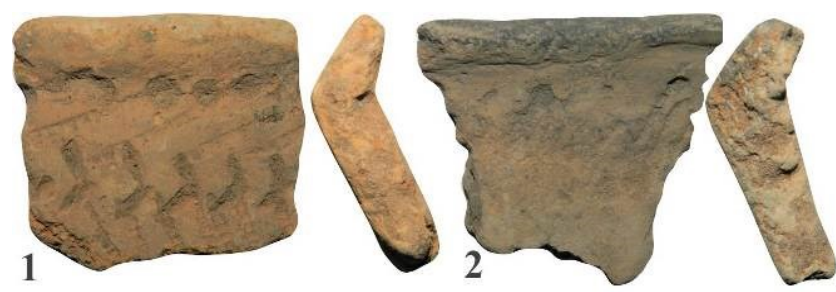

Накольчатая керамика третьего раскопа сопоставляется не с татарско-азибейским типом, а с накольчатой посудой Нижне-Марьянских и Матюшинских стоянок приустьевой части р. Камы или подобной керамикой Дубовогривской II стоянки в ИкскоБельском междуречье [31, с. 50-51], для которых характерна толстостенность сосудов, закрытость форм и срезы венчиков, в том числе с наплывами на внутренней стороне. Подобная керамика является продолжением развития накольчатой керамики щербетьского типа памятников с сильным влиянием камской культуры развитого этапа. В этот комплекс, по-видимому, стоит включить керамику, украшенную насечкой и внутренними наплывами под венчиками. Такие выводы подтверждаются самим Р.С. Габяшевым, который отмечает факт неолитоидности наиболее раннего керамического комплекса в раскопе, где сочетаются признаки камской неолитической культуры хуторского типа и накольчатой керамики [35, с. 24].
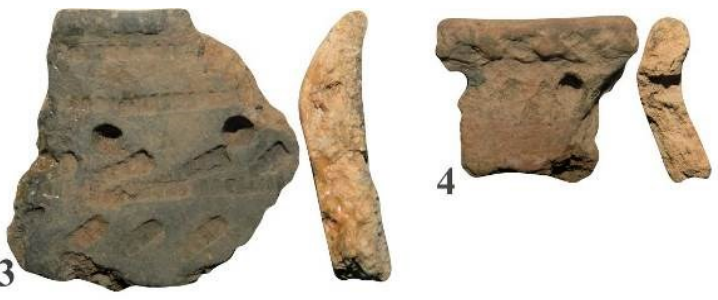
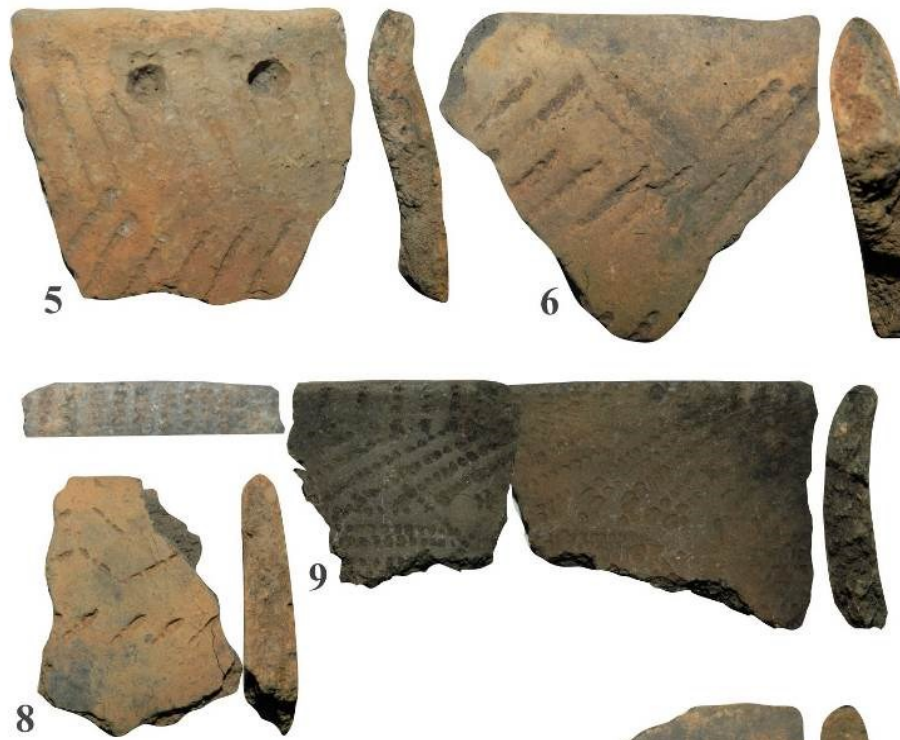
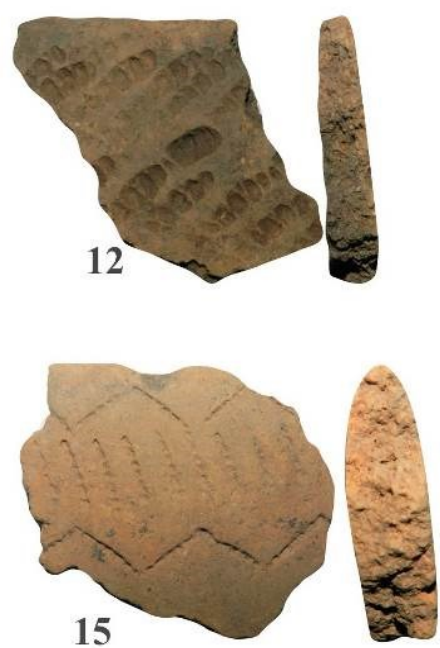
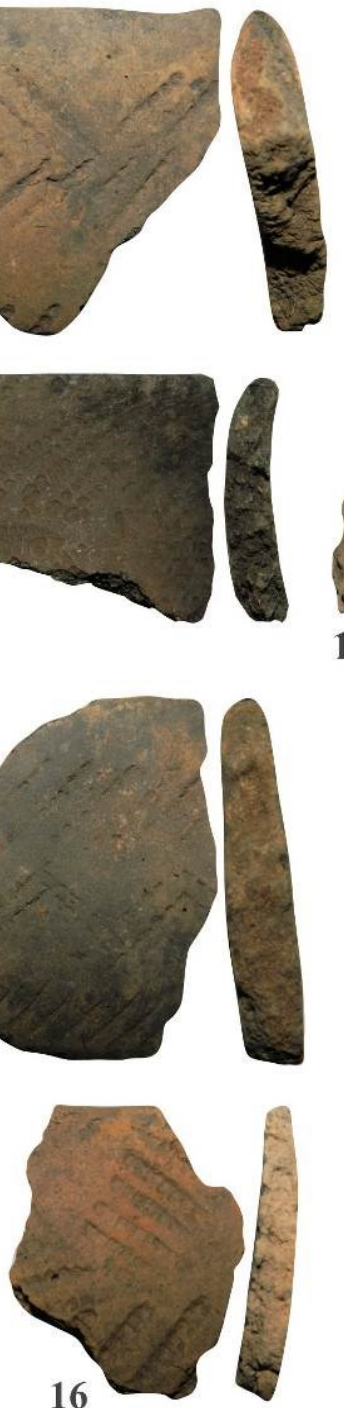

0

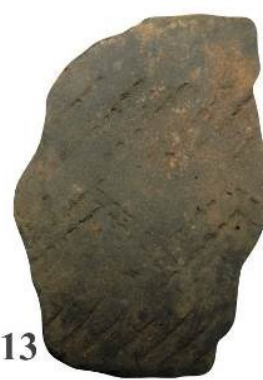

10
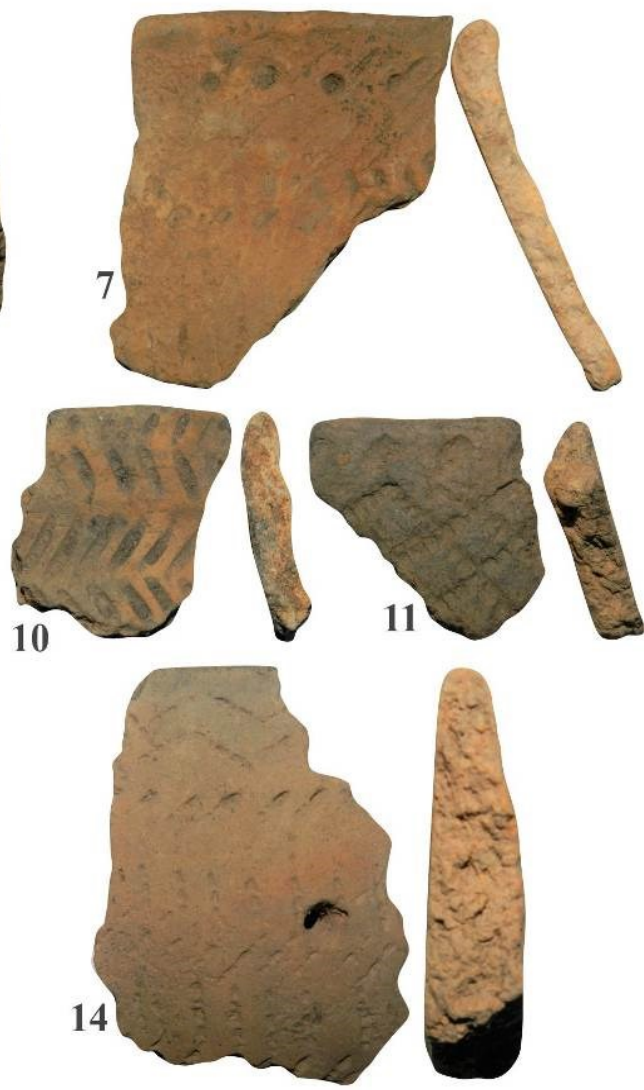

17

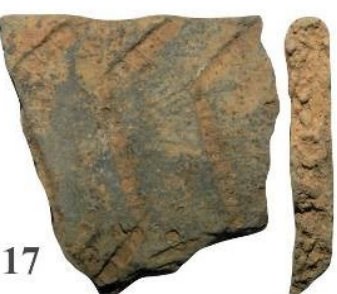

$5 \mathrm{~cm}$

Рисунок 4 - Керамика Русско-Азибейской стоянки. 1-17-Образцы с Русско-Азибейской стоянки 
Новоильинская керамика была зафиксирована нами и в раскопах №№ I-II Русско-Азибейской стоянки [20-21] с массивом воротничковой керамики, выделенной Р.С. Габяшевым в русско-азибейский тип [34]. Следует обратить внимание на то, что некоторые исследователи абсолютное большинство посуды со стоянки соотносят с русско-азибейским типом [37]. Наши наблюдения позволяют не согласиться с такими выводами. Отдельные типы и формы посуды стоянки $[37$, с. 77 , рис. $6: 1-2,4,7-9,18-20$, c. 78 , рис. $7: 1-8,11-17,20$, с. 79 , рис. $8: 1,4,6-11$, 13] находят широкие аналогии в керамике левшинского этапа камской культуры на памятниках ИкскоБельского междуречья, для которых характерна подобная профилировка сосудов. Другая часть, представленная посудой со слегка отогнутыми венчиками, отожествляется с материалами новоильинских и красномостовских памятников $[10$, с. 63 , рис. $2 ; 38$, c. 307, рис. 20: 9]. При этом некоторые новоильинские и воротничковые фрагменты типологически очень близки [39, с. 57].

По отчетам, хранящимся в ОПИ ИА РАН, удалось установить, что воротничковая керамика и керамика с подцилиндрическими, отогнутыми и слабо выраженными Г-образными венчиками залегают вместе, в том числе на дне различных ям [20, с. 93]. Таким образом, одновременное существование этой керамики возможно, но из-за нахождения культурных остатков на дюне и в песчаном грунте, не доказуемо.

Татарско-Азибейское II поселение открыто в 1958 г. В.Ф. Генингом [33]. В 1970-1972 годах на

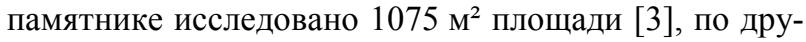
гим данным она равна 1194 м² $^{2}$ без учета разведочной траншеи 1970 г. [21].

Памятник занимает северо-западную окраину надлуговой террасы. Высота площадки над уровнем высыхающего заболоченного старичного озера составляет 4-5 м. Площадь распространения подъемного материала составляла 30 тыс. $\mathbf{m}^{2}$ [3, с. 40].

Характеристика керамики «близкой флажковой» выглядит следующим образом: толщина 0,7-0,9 см, в примесях к глиняному тесту содержится шамот и песок, форма срезов венчиков разнообразна: скошенные вовнутрь с наплывом - 7 экз., скошенные вовнутрь без наплыва - 9 экз., плоскосрезанные с наплывом 9 экз., плоскосрезанные без наплыва - 19 экз., приостренные - 17 экз., слегка отогнутые наружу 16 экз. Донца: округлые - 7 экз., плоские -4 экз., небольшие вогнутые вовнутрь - 3 экз. Орнаментальное поле имело свободные зоны. Из элементов орнамента отмечены: вертикальный зигзаг, пояса из наклонных оттисков гребенчатого штампа, различные зигзагообразные линии, «флажки», «косая решетка». [21, с. 50-51] (рис. 5).

На Татарско-Азибейском II поселении керамика, по терминологии Р.С. Габяшева «близкая флажковой», отмечена на некоторых участках раскопа - в заполнении объектов № 1,3 , очагах 4,5 и ямах 1,5 совместно с накольчатой $[21$, с. 52]. Р.С. Габяшев отмечает, что синхронизовать эти два керамических типа на поселении можно с известной долей осторожности [31, с. 66, 69].

Стоянка Сауз I. Памятник расположен на южном берегу старичного озера Саузбаш, в 1,2 км западнее д. Саузово (Республика Башкортостан) на террасе высотой 4,5 м над уровнем озера. Стоянка впервые обследована Камской экспедицией в 1955-1956 годах $\left(136 \mathrm{~m}^{2}\right)$ [24, с. 11]. В 1980-1981 гг. на стоянке Сауз I проводятся новые широкомасштабные стационарные исследования. При вскрытии 544 м² было изучено пять котлованов от жилищных построек и выявлено 3184 фрагмента керамики. К новоильинской культуре было отнесено 45,32\% керамики [6, с. 3-21].

Характеристика сосудов следующая: керамика с примесью шамота и толщиной стенок 0,7-1,2 см. Большинство верхних частей сосудов прямостенно, но зафиксированы и загнутые вовнутрь и незначительно отогнутые наружу. Срезы венчиков округлые, плоские и плоскоскошенные. На ряде сосудов с внутренней стороны имелся незначительный наплыв. Керамика украшалась оттисками среднезубого гребенчатого штампа и коротким крупнозубчатым овальным штампом. Орнаментальным композициям присущи: различные наклонные ряды, вертикальный зигзаг, прямопоставленные ряды, чередующиеся с наклонными оттисками короткого штампа, ромбы [6, с. 3-4] (рис. 6: 1-6).

На стоянке Сауз І отмечено минимальное присутствие посуды камской культуры и здесь примерно одинаковое соотношении новоильинской и гаринской керамики. Причем во всех четырех жилищах новоильинская керамика зафиксирована совместно с гаринской вплоть до пола построек [6, с. 16, табл. 2]. Аналогичные стратиграфические условия для новоильинской и гаринской посуды отмечены на поселении Сауз II [40, с. 50-51].

Поселение Сауз II расположено в 700-800 м западнее стоянки Сауз І. В 1980 г. здесь было вскрыто

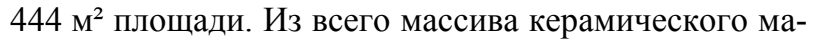
териала было выделено 1384 фрагментов по техникотипологическим признакам, отнесенных к новоильинской культуре [40, с. 46-47]. В целом керамический комплекс новоильинской культуры стоянки Сауз II идентичен Саузу I. Из отличий можно выделить присутствие утолщенных венчиков (7\%), более широкое распространение (41\%) орнамента с использованием короткого овального оттиска из 4-6 зубцов [40, с. 47] (рис. 6: 7-9).

Старо-Нагаевский могильник находится в 4 км к северо-западу от д. Староянзигитово Краснокамского р-на Республики Башкорстостан, на останце правого берега р. Белая. Назван по д. Старонагаево (ныне не существует). Памятник был выявлен на территории Старо-Нагаевской II стоянки в 1969 г. В.С. Стоколосом [26]. С учетом разведочных траншей было исследовано 890 м² площади. Всего раскопами было выявлено и исследовано 25 погребений $[28$, с. 22-23, 35]. Могильные ямы имели устойчивые признаки: глубина (45-55 - 76-86 см от дневной поверхности или 5-36 см от уровня материка), ориентировка (СВ-Ю3, С3-ЮВ), четкие прямоугольные очертания; в 16 погребениях отмечены различные поделки из камня и кости (амулеты, подвески) [28, c. 24].

Могильные ямы сильно потревожены распашкой, фрагменты от развалов сосудов в погребениях были зафиксированы на других участках раскопа и могильных ямах. Размеры ям в большинстве своем невелики и, возможно, предназначались для детей. В двух погребениях отмечены сильно истлевшие костяки взрослых, без инвентаря [28, с. 29-30]. 

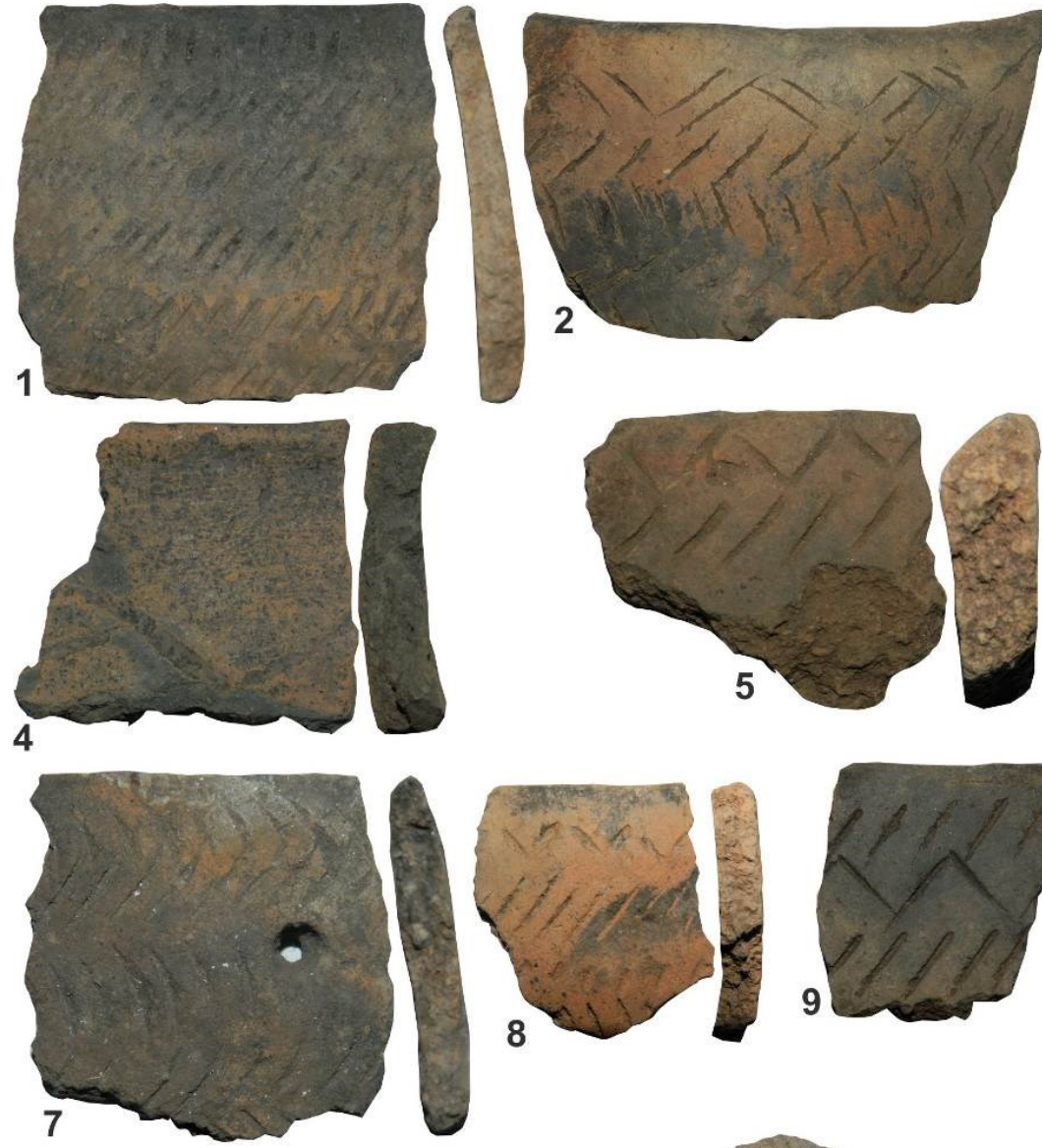

\section{9}
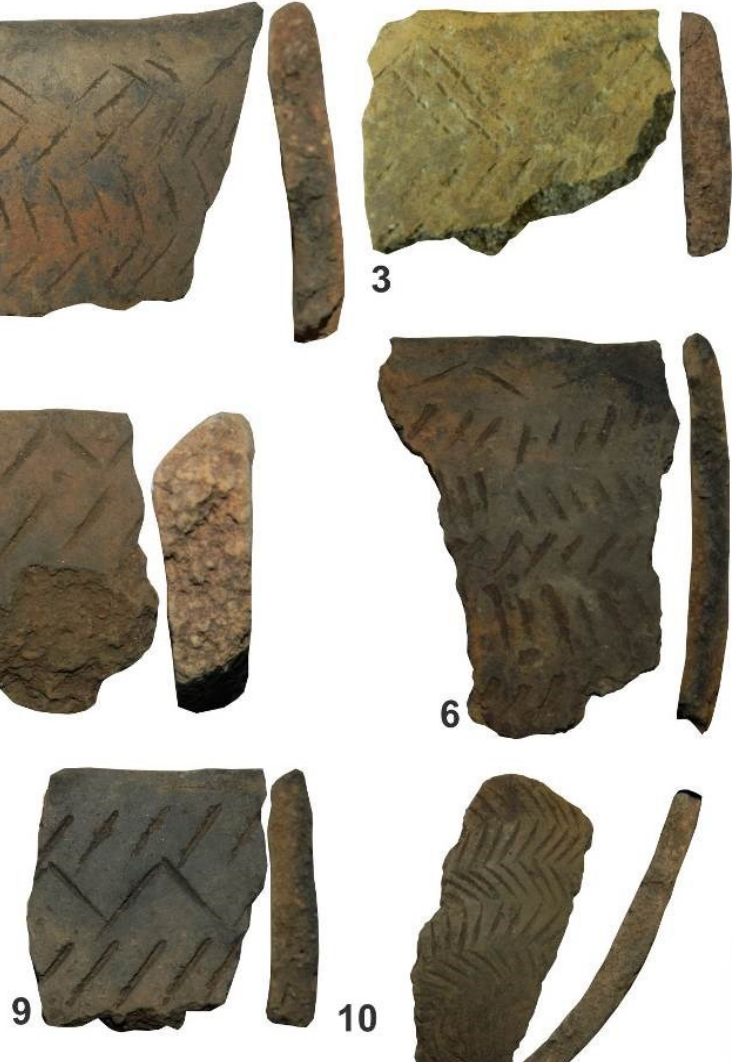

3

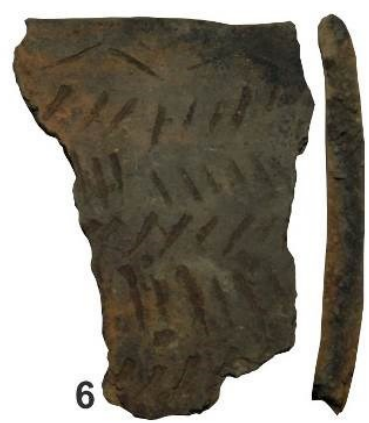

10
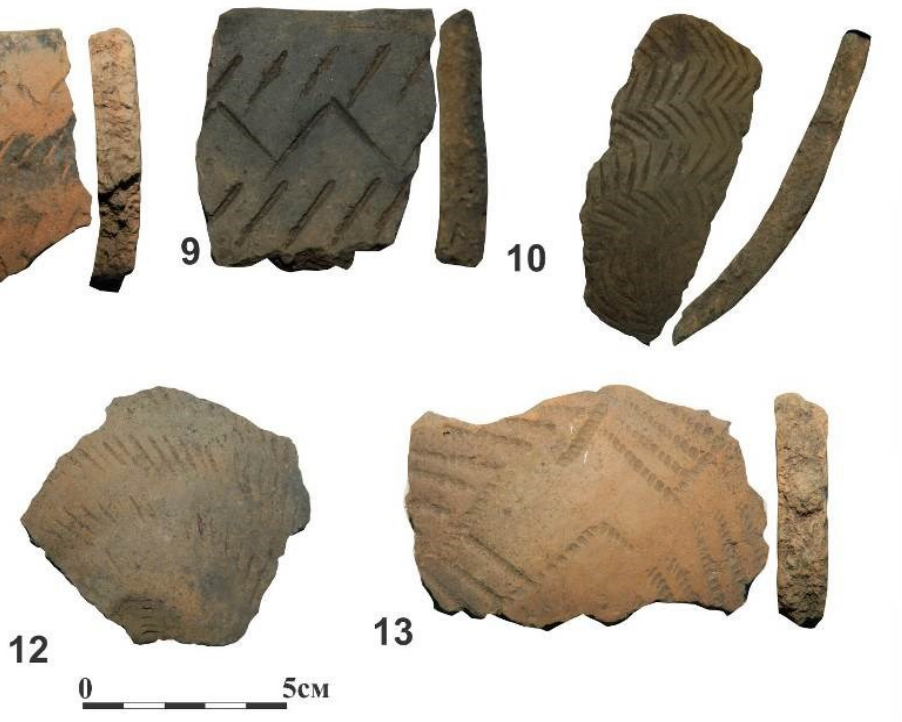

13

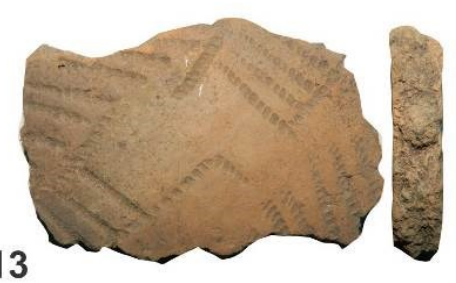

11

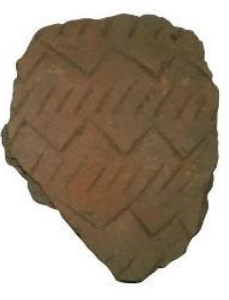

0 $5 \mathrm{~cm}$

Рисунок 5 - Керамика Татарско-Азибейского II поселения.

1-13 - Образцы с Татарско-Азибейского II поселения

В большинстве погребений, в засыпке и на дне ям фиксировались скопления и развалы керамики от пяти до 483 фрагментов от 1-5 сосудов. В некоторых случаях скопления фиксировались полосой вдоль стенок могильных ям. Несколько крупных развалов выявлены вне могильных ям, их фрагменты фиксировались с первого штыка и до материка. Всего удалось выделить 36 сосудов [28, с. 34].

Крупные реконструируемые сосуды имели открытые или закрытые формы, округлые или уплощенные донца, слегка утонченные, округлые, скошенные вовнутрь и незначительно отогнутые наружу венчики, иногда с незначительными наплывами с внутренней стороны. Все сосуды имели примеси шамота и песка. В одном случае с такими примесями сочетается неустановленная добавка в глиняное тесто, от чего керамика кажется скользкой на ощупь $[28$, c. 33]. Толщина стенок некоторых сосудов доходит до 1,3 см, а миниатюрные сосудики были тонкостенными и непрочными.

Bce сосуды украшены в гребенчатой технике. Орнамент покрывает всю внешнюю поверхность посуды отпечатками длинной, средней и короткой гребенки. Из элементов орнамента устойчивыми явля- ются: «косая решетка», чередующиеся наклонные линии (вертикальный зигзаг), отпечатки коротких наклонных оттисков (горизонтальный зигзаг), горизонтальные ряды «шагающей» гребенки, отпечатки (вдавления) углом штампа. Характерной особенностью сосудов является поясок ямочных вдавлений (или вдавлений углом штампа) под срезом венчика (рис. 7: 10-14).

Керамика Старо-Нагаевского могильника представляет исключительный интерес. По ряду признаков, таких как: закрытость форм некоторых сосудов, поясок ямочно-жемчужных вдавлений под венчиком, орнамент (вертикальный зигзаг, шагающая гребенка), небольшие наплывы под венчиками с внутренней стороны, она сопоставима с керамикой левшинского этапа камской культуры. Другие маркеры: открытые формы, утонченные венчики, разреженность орнамента, использование крупногребенчатого и овального короткого штампа - являются отличительными признаками новоильинской керамики. Таким образом, материалы могильника демонстрируют переход или транформацию левшинской керамики камской культуры в новоильинскую. Стоит отметить, что такие выводы озвучиваются не впервые [41, с. 9]. 

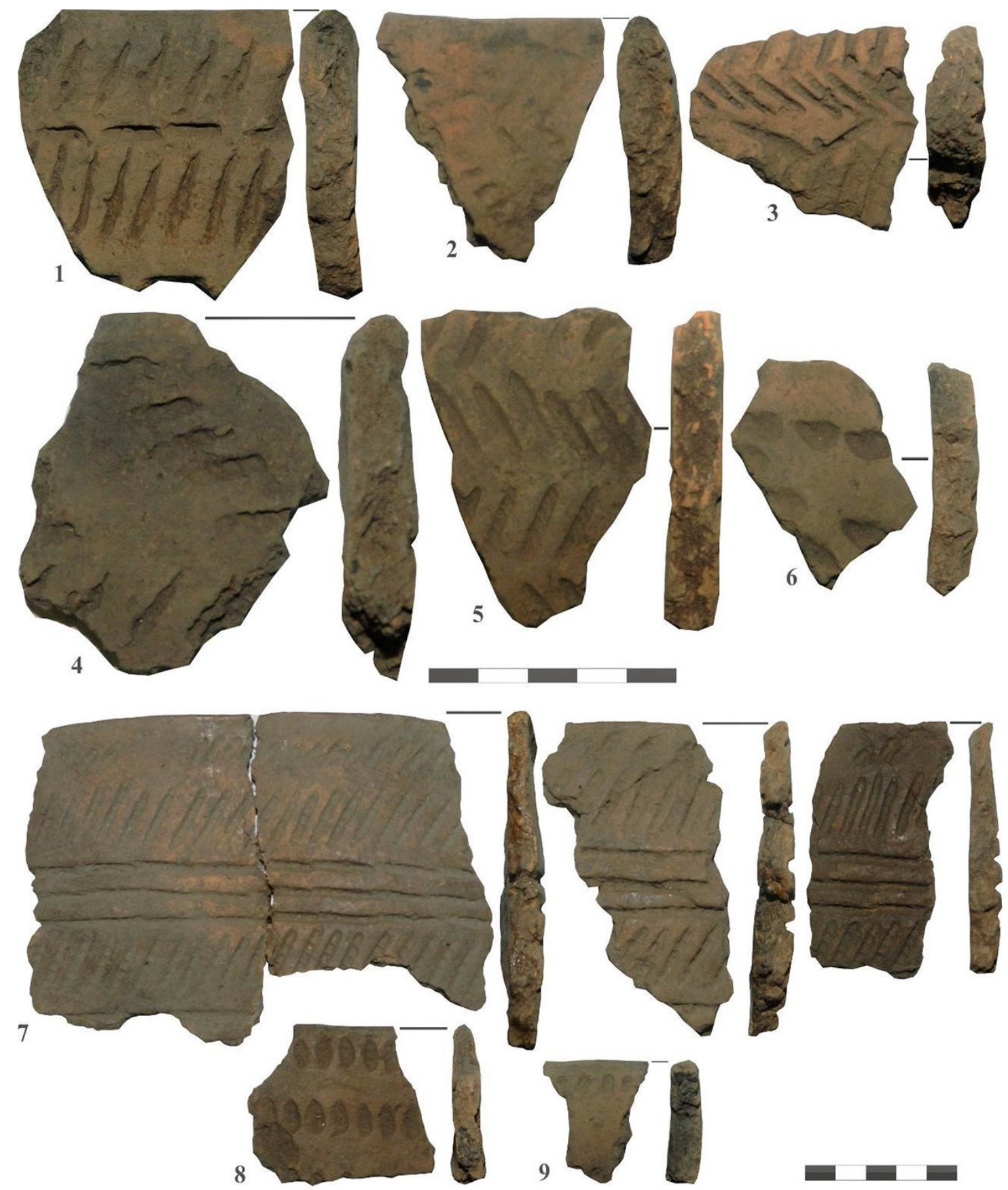

Рисунок 6 - Новоильинская керамика стоянки Сауз I (1-7), поселения Сауз II (8-11)

Не случайным выглядит и находка рядом с погребением № 21 - скопление фрагментов от придонной части сосуда с плоским и вогнутым донцем [28, c. 35,37 , рис. 20: 2], которое, судя по характеру орнаментации, очень похоже на накольчатую посуду. Аналогичные донца нами зафиксированы в коллекции Татарско-Азибейского II поселения, хранящейся в фондах Музея археологии ИА АН РТ.

Давлекановское поселение расположено на левом берегу Демы, на северо-восточной окраине города Давлеканово Республики Башкортостан. Исследовано Г.Н. Матюшиным в 1962-1963, 1967 и 1969 гг. $\left(589 \mathrm{M}^{2}\right)$. Культурный слой памятника перемешан и включает культурные остатки различных эпох. По опубликованным Г.Н. Матюшиным материалам с памятника [42; 43; 29] возможно выделение керамики, которая по типологии хорошо сопоставляется с новоильинской посудой. Точное количество таких сосудов, найденных на поселении, установить сложно. Дело в том, что частично такая керамика была отнесена к агидельской энеолитической культуре и составляла, по мнению автора раскопок, один комплекс с «раковинной» и воротничковой посудой [43], другая часть была отнесена к прибельской неолитической культуре [29]. В настоящее время часть материалов памятника хранится в гимназии № 1505 г. Москвы и частично опубликована [44; 45].

Характеристика новоильинской посуды Давлекановского поселения такова: сосуды имели круглодонную форму с примесью шамота (в некоторых случаях раковины?), кроме гребенчатого штампа отмечены украшения овальными ямками (или вдавлениями от угла штампа), под венчиком поясок ямочно-жемчужных вдавлений. Превалирует короткий гребенчатый штамп из 3-5 зубцов, венчики - скошенные вовнутрь или утончены, иногда украшенные орнаментом по срезу [43, с. 191-192, 233, табл. 84: 5, $11,13,15,17-19$, с. 234 , табл. $85: 1$, с. 235 , табл. 86 : 1, 4, с. 236, табл. 87: 2-4, 7-8] (рис. 7: 1-9). 

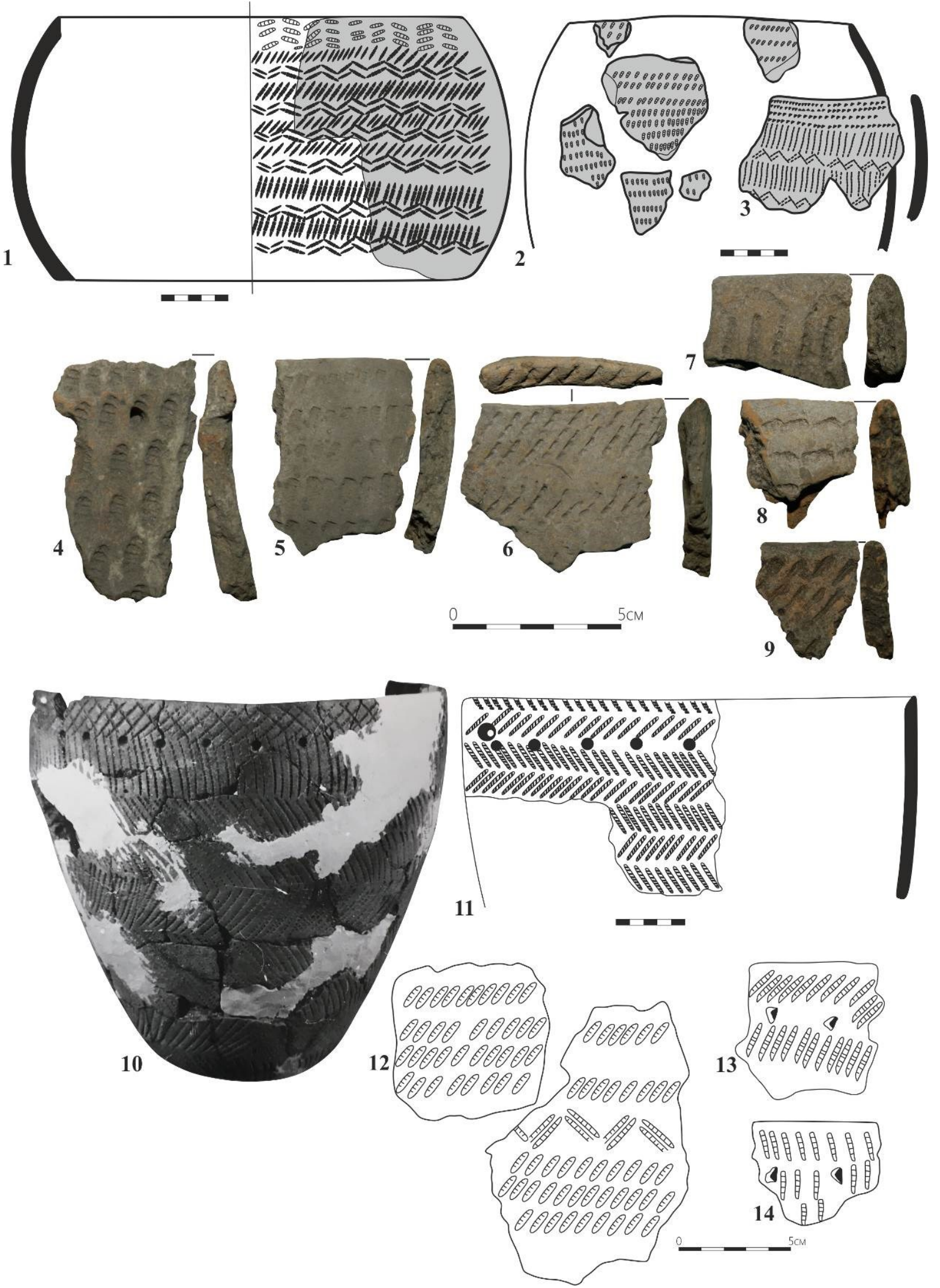

Рисунок 7 - Новоильинская керамика Давлекановского поселения (1-9), Старо-Нагаевского могильника (10-14) по В.С. Стоколосу [26-27]

Сложный характер археологических памятников (смешанность культурного слоя на песчаных дюнах), содержащих керамику новоильинского типа, делает крайне затруднительным обращение к каменному инвентарю и выделение каменных орудий, характерных для новоильинской культуры.

Приведенный выше анализ керамического комплекса новоильинской культуры позволяет утвер- ждать, что по ряду показателей эта посуда очень близка гребенчатой керамике камской культуры. И не случайно, при открытии этого типа керамики она интерпретировалась как «позднейший вариант позднелевшинской» керамики [2, с. 180].

Отсутствие четких данных по стратиграфии и планиграфии, небольшая серия абсолютных дат не дают четкого представления о времени формирова- 
ния и развития новоильинской культуры. Имеющиеся в настоящее время данные позволяют утверждать, что к последней четверти V тыс. cal BC самарские воротничковые (ивановские) традиции исчезают. В Нижнем Прикамье сформировывается специфичная керамика «неолитоидного» облика. При этом на новоильинской керамике Икско-Бельского междуречья фиксируются особенности, которые являются левшинскими реминисценциями и не характерны для Среднего и Верхнего Прикамья, это - наплывы с внутренней стороны венчика, ряды ямочно-жемчужных вдавлений под венчиком, закрытые формы посуды и орнамент «шагающая» гребенка.

Близость керамических комплексов новоильинских памятников с поздненеолитической керамикой камской культуры, наличие радиоуглеродных дат, отсутствие признаков металлообработки позволяют высказать предположение о том, что функционирование новоильинских памятников в Нижнем Прикамье происходило на границе каменного века и эры ранних металлов. Нет никаких убедительных доказательств кардинальной перемены и переоценки видов труда и культурной переориентации населения, оставившего памятники новоильинского культурного типа, а металлические изделия, найденные на смешанных памятниках, исследователи зачастую относят к гаринской культуре [15, с. 47].

Надо сказать, что эти данные не согласуются с мнением отдельных исследователей, отмечающих все же наличие металлообработки у носителей новоильинской культуры Икско-Бельского междуречья [46, c. 18].

Кроме, собственно, камской неолитической культуры, в формировании новоильинских памятников, по мнению ряда исследователей, принимали участие группы населения с ямочно-гребенчатой керамикой, которые относятся к балахнинской культуре (по А.Х. Халикову и В.В. Никитину) [13, с. 35]. Материалы памятников Нижнего Прикамья (Икско-Бельского междуречья) противоречат этому. Ямочно-гребенчатые компоненты, безусловно, сыграли определенную роль в формировании красномостовского культурного типа в Марийском Поволжье, что наглядно отразилось на самой керамике, особенно на ее орнаментальных мотивах [38]. На новоильинской керамике Икско-Бельского междуречья пояски по тулову в качестве разделительных зон из ямочных вдавлений минимальны. Здесь имеется лишь небольшой процент посуды с различными ямчатыми вдавлениями. Широкое распространение таких мотивов на Верхнем и Среднем Прикамье может объясняться не участием балахнинского населения Марийского и Казанского Поволжья, а отдельными инфильтрациями групп с ямочно-гребенчатой керамикой Европейского северо-востока.

Другим немаловажным моментом остается вопрос о том, какие именно южные компоненты приняли участие или оказали воздействие на формирование новоильинского типа. Исследователи лесостепных энеолитических культур высказывали предположения, что в становлении лесных культур меднокаменного века - гаринской, борской и средневолжского варианта волосовской культур - прини- мали участия токские [47, с. 79-80; 48, с. 49-57] и даже алтатинские элементы [48, с. 55]. С выводами о существовании связей между лесостепными и лесными культурами с комплексами раковинной керамики, на наш взгляд, следует согласиться. Но, по нашему мнению, влияние токских традиций отчетливо фиксируется уже на новоильинской керамике (рис. 8). Украшение орнаментом срезов венчиков, использование короткого овального штампа, некоторые формы венчиков (профилированные и незначительно отогнутые наружу) и орнаментальные мотивы находят параллели в токской керамике. Такие выводы подкрепляются датами по ${ }^{14} \mathrm{C}$, устанавливающими синхронность токских и новоильинских памятников $[49 ; 50 ; 13 ; 16]$, а также присутствием новоильинской керамики далеко от лесного Прикамья - в Оренбуржье, совместно с токским типом керамики $[51$, c. 264].

Если синхронизировать данные лесных и лесостепных культур со второй четверти - середины V тыс. cal BC, то вырисовывается следующая картина: первое наиболее сильное влияние лесостепи на лесной, поздний неолит фиксируется на левшинском этапе камской культуры, когда в керамических комплексах проявляется значительный удельный вес южных элементов, полученных от ивановского типа самарской культуры [50, с. 183-184], наиболее ярко отразившихся появлением на керамике воротничковых утолщений с внешней стороны венчика. При этом сама технология керамического производства не перенималась лесными гончарами, а «воротничковая мода» угасла к $4200 \mathrm{cal}$ BC.

На смену ивановскому типу самарской культуры в лесостепи, после некоторого сосуществования с ней приходит токский тип керамики [50, с. 131 , табл. 9, с. 132, табл. 10], время функционирования токской керамики определяется значениями 43503640 cal ВC (при вероятности 68\%) [49, с. 24]. В это время в лесной зоне Нижнего Прикамья распространяется новая волна влияния южных культур (токского типа), отразившаяся в формах и орнаменте новоильинской посуды. Состав глиняного теста новоильинской посуды продолжает оставаться без изменений, как и сама посуда в целом: толщина и форма большинства сосудов, обильная примесь шамота, состав орнамента и его мотивы на большинстве керамической посуды. Нет никаких убедительных доказательств о наличии металлопроизводства у носителей новоильинской культуры.

Подводя итоги, хотелось бы отметить, что переход от неолита к энеолиту в южной части лесной зоны не был процессом мгновенным и «взрывным». На данном этапе исследований можно утверждать, что влияние энеолитических культур лесостепного Поволжья на неолитическую камскую культуру носило характер многокомпонентного воздействия, которое, впрочем, не было воспринято в полном объеме. Только материалы поздних новоильинских памятников демонстрируют трансформацию (или заимствование) традиции изготовления глиняной посуды и появление раковинной (пористой) керамики на памятниках Верхней и Средней Камы [14, с. 27], на Вятке [10, с. 60-62] и в устье р. Белой [6, с. 9-10]. 

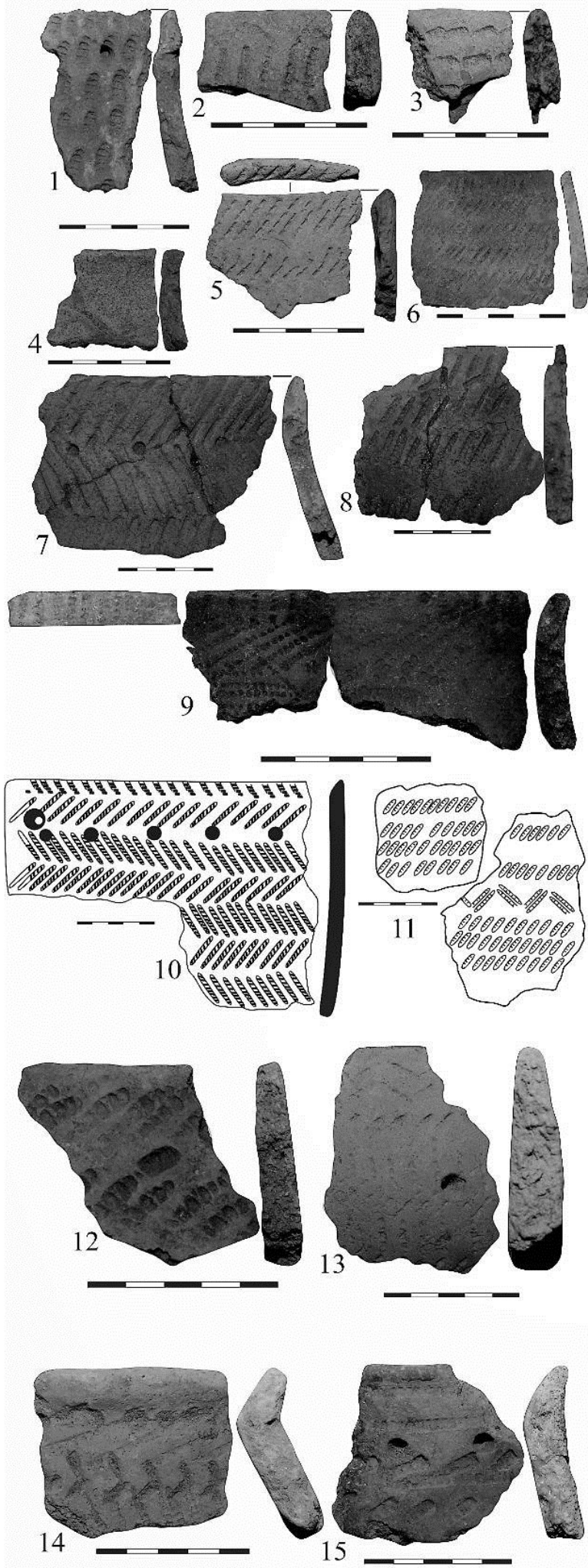

Рисунок 8 - Новоильинская тип керамики Нижнего Прикамья (1-15),

Токский тип керамика Волго-Уральского междуречья (16-28) (16-26 - по Н.Л. Моргуновой [50])

\section{Список литературы:}

1. Бадер О.Н. Камская археологическая экспедиция в 1958 г. // Краткие сообщения Института археологии. 1961. Вып. 85. С. 73-85.

2. Бадер О.Н. Поселения турбинского типа в Среднем Прикамье // Материалы и исследования по археологии СССР. 1961. № 99. М.: АН СССР. 199 с.

3. Габяшев Р.С. Второе Татарско-Азибейское поселение // Древности Икско-Бельского междуречья /
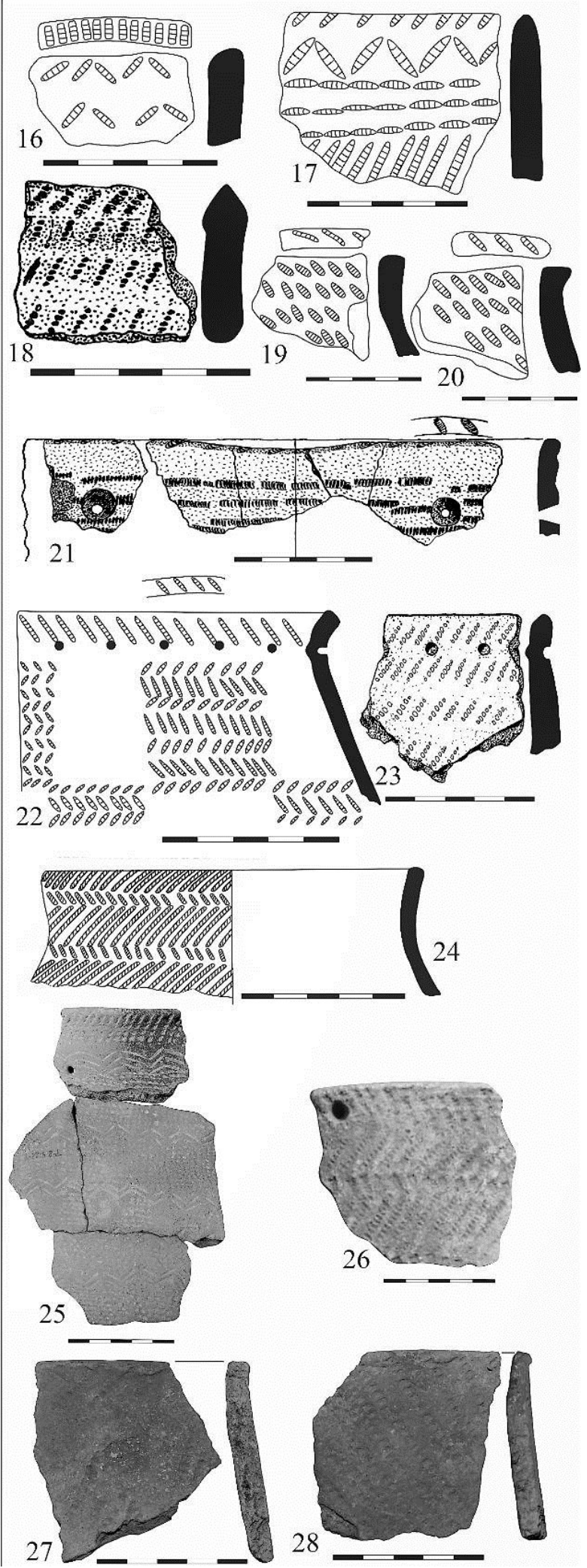

отв. ред. О.Н. Бадер. Казань: ИЯЛИ им. Г. Ибрагимова КФАН СССР, 1978. С. 40-66.

4. Гусенцова Т.М. Поселение Кочуровское IV в бассейне р. Кильмезь // Памятники эпохи неолита и бронзы в бассейне р. Вятки. Ижевск / науч. ред. С.В. Ошибкина. Ижевск: НИИ при Совете Министров Удмуртской АССР, 1980. С. 83-93.

5. Наговицын Л.А. Из истории изучения памятников эпохи энеолита и бронзы в бассейне р. Вятки // Памятники эпохи неолита и бронзы в бассейне р. Вятки. 
Ижевск / науч. ред. С.В. Ошибкина. Ижевск: НИИ при Совете Министров Удмуртской АССР, 1980. С. 3-18.

6. Выборнов А.А., Обыденнов М.Ф., Обыденнова Г.Т. Поселение Сауз I в устье р. Белой // Эпоха меди юга Восточной Европы: межвуз. сб. науч. тр. / отв. ред. Н.Я. Мерперт. Куйбышев: Куйбышевский педагогический институт, 1984. С. 3-21.

7. Наговицын Л.А. Периодизация энеолитических памятников Вятского края // Проблемы изучения каменного века Волго-Камья / отв. ред. Л.А. Наговицын. Ижевск: НИИ при Совете Министров Удмуртской АССР, 1984. С. 89-123.

8. Наговицын Л.А. Новоильинская, гаринско-борская и юртиковская культуры // Серия: Археология СССР. Эпоха бронзы лесной полосы СССР / отв. ред. О.Н. Бадер, Д.А. Крайнов, М.Ф. Косарев. М.: Наука, 1987. С. 28-34.

9. Наговицын Л.А. Культурно-хронологическое соотношение гаринских и борских памятников Прикамья // Энеолит лесного Урала и Поволжья: мат-лы II полевого симпоз. по пробл. археологии эпохи камнябронзы лесн. полосы Европ. части СССР / отв. ред. Л.А. Наговицин. Ижевск: УИИЯЛ, 1990. С. 82-96.

10. Наговицын Л.А. Дискуссионные проблемы в изучении новоильинской культуры // Вопросы археологии Урала: сб. науч. тр. / отв. ред. В.Т. Ковалева. Екатеринбург: УрГУ, 1993. С. 59-76.

11. Никитин В.В. Красномостовские поселения финального неолита (предварительный анализ) // Проблемы изучения каменного века Волго-Камья / отв. ред Л.А. Наговицын. Ижевск: НИИ при Совете Министров Удмуртской АССР, 1984. С. 31-43.

12. Никитин В.В. Медно-каменный век Марийского края (середина III - начало II тыс. до н.э.). Йошкар-Ола: Марийское книжное изд-во, 1991. 152 с.

13. Лычагина Е.Л., Выборнов А.А. К вопросу о происхождении и хронологии новоильинской энеолитической культуры // Научный Татарстан. Гуманитарные науки. Археология и история. 2009. № 2. C. $33-37$.

14. Мельничук А.Ф. Поселение Усть-Очер I энеолитический памятник в Оханском Прикамье и проблемы изучения поселений новоильинского культурного круга // Вестник Пермского университета. 2011. Вып. 1 (15). С. 22-36.

15. Денисов В.П., Мельничук А.Ф. Поселение Гагарское III в системе новоильинских древностей Пермского Приуралья // Вестник Пермского университета. 2014. Вып. 1 (24). С. 44-59.

16. Лычагина Е.Л. Хронологические рамки неолитических и постнеолитических культур Среднего Предуралья // Уральский исторический вестник. 2018. Вып. 3. С. 87-96.

17. Выборнов А.А. Неолит Волго-Камья. Самара: Изд-во СГПУ, 2008. 490 с.

18. Габяшев Р.С., Старостин П.Н. Отчет о раскопках Дубовогривской второй стоянки // Отчет о работе Татарского отряда Нижнекамской археологической экспедиции в 1969 г. Т. 1 // Архив ИА РАН. Р-1, № 3916.

19. Габяшев Р.С., Старостин П.Н. Отчет о работах, проведенных летом 1971 г. в зоне затопления Нижнекамской ГЭС в пределах Мензелинского и Наб.-Челнинского районов ТАССР // Отчет о полевых исследованиях Татарского отряда Нижнекамской археологической экспедиции в 1971 г. Т. 1 // Архив ИА РАН. Р-1, № 4601.
20. Габяшев Р.С., Косменко М.Г., Старостин П.Н. Отчет о раскопках Русско-Азибейской стоянки // Отчет Татарского отряда Нижнекамской археологической экспедиции. Т. 1 // Архив ИА РАН. Р-1, № 4121.

21. Габяшев Р.С. Отчет о работах, проведенных летом 1972 г. в зоне затопления Нижнекамской ГЭС в пределах восточных районов ТАССР // Отчет о работе Татарского отряда Нижнекамской археологической экспедиции в 1972 г. Т. 1 // Архив ИА РАН. Р-1, № 6208.

22. Халиков А.Х. Отчет I отряда археологической экспедиции ИЯЛИ КФАН СССР о работах, проведенных в Мензелинском районе Татарской АССР // Отчет о полевых работах археологической экспедиции ИЯЛИ КФАН СССР за 1958 г. // Архив ИА АН РАН. Р-1, № 1771.

23. Габяшев Р.С., Старостин П.Н. Итоги раскопок Игимской стоянки и могильника // Отчет Татарского отряда Нижнекамской археологической экспедиции. Т. 1 // Архив ИА РАН. Р-1, № 4121.

24. Бадер О.Н., Калинина И.В. Саузовская I стоянка // Труды Камской археолого-этнографической экспедиции ПГПУ. 2003. Вып. 3. С. 11-30.

25. Выборнов А.А., Елизаров А.Б., Овчинникова Н.В. Поселение Сауз II и проблема периодизации эпохи раннего металла Нижней Белой // Древности Среднего Поволжья / отв. ред. Г.И. Матвеева. Куйбышев: КГУ, 1985. С. 34-36.

26. Стоколос В.С. Научный отчет о результатах археологических исследований за 1969 г. // Архив ИА РАН. Р-1, 3944а (альбом иллюстраций).

27. Стоколос В.С. Отчет о полевых работах 1970 г. // Архив ИА РАН. Р-1, 4358а (альбом иллюстр.).

28. Стоколос В.С. Старо-Нагаевский могильник // Эпоха меди юга Восточной Европы: межвуз. сб. науч. тр. / отв. ред. Н.Я. Мерперт. Куйбышев: Куйбышевский педагогический институт, 1984. С. 22-42.

29. Матюшин Г.Н. Неолит Южного Урала. Предуралье. М.: Ин-т этнологии и антропологии им. Н.Н. Миклухо-Маклая, 1996. 301 с.

30. Габяшев Р.С., Старостин П.Н. Жилища эпохи бронзы второй Дубовогривской стоянки // Древности Икско-Бельского междуречья / отв. ред. О.Н. Бадер. Казань: ИЯЛИ им. Г. Ибрагимова КФАН СССР, 1978. С. 109-120.

31. Габяшев Р.С. Население Нижнего Прикамья в V-III тыс. до н.э. Казань: Изд-во ФЭН, 2003. 222 с.

32. Габяшев Р.С. Энеолит Нижнего Прикамья // Очерки по археологии Татарстана: учебное пособие / ред. кол. П.Н. Старостин и др. Казань: Изд-во Школа, 2001. С. 44-55.

33. Генинг В.Ф. Отчет об археологических разведках в низовьях левобережья р. Белой, произведенных II отрядом археологической экспедиции КФАН СССР летом 1958 г. // Отчет о полевых работах археологической экспедиции ИЯЛИ КФАН СССР за 1958 г. // Архив ИА АН РАН. Р-1, № 1771. Казань, 1959.

34. Габяшев Р.С. Русско-Азибейская стоянка // Древности Икско-Бельского междуречья / отв. ред. О.Н. Бадер. Казань: ИЯЛИ им. Г. Ибрагимова КФАН CCCP, 1978. С. 22-39.

35. Габяшев Р.С. Итоги раскопок III Русско-Азибейской стоянки // Об исторических памятниках по долинам Камы и Белой / отв. ред. А.Х. Халиков. Казань: Ин-т яз., лит. и истории, 1981. С. 11-24. 
36. Галимова М.Ш. Кремневые комплексы мезолита - энеолита северной части Икско-Бельского междуречья // Поволжская археология. 2012. № 2. C. 6-28.

37. Шипилов А.В. Материальная культура и хозяйство населения раннего энеолита Икско-Бельского междуречья // Актуальные вопросы Российской археологии: сб. стат. Вып. 1. Казань: ЦИАИ, 2014. C. 69-99.

38. Никитин В.В. На грани эпохи камня и металла. Средневолжский вариант волосовской культурноисторической общности: монография. Йошкар-Ола: Мар. гос. ун-т, 2017. 765 с. (Материалы и исследования по археологии Поволжья и Урала. Вып. 10).

39. Морозов В.В. Левшинский этап камской культуры в Нижнем Прикамье и его особенности // XXI Уральское археологическое совещание, посв. 85-летию со дня рожд. Г.И. Матвеевой и 70-летию со дня рожд. И.Б. Васильева: мат-лы всерос. науч. конф. с междунар. участием. Самара: Изд-во СГСПУ, 2018. С. 53-57.

40. Выборнов А.А., Овчинникова Н.В. Итоги изучения поселения Сауз II (1980 г.) // Древние и средневековые культуры Поволжья / отв. ред. Г.И. Матвеева. Куйбышев: КГУ, 1981. С. 33-52.

41. Выборнов А.А. Неолит и эпоха раннего металла правобережья Нижней Белой: автореф. дис. ... канд. ист. наук. Л., 1984. 16 с.

42. Матюшин Г.Н. Неолитическое поселение и погребение у г. Давлеканово на Южном Урале // Coветская археология. 1970. Вып. 4. С. 160-168.

43. Матюшин Г.Н. Энеолит Южного Урала. М.: Наука, 1982. 329 с.

44. Морозов В.В., Ставицкий В.В. Стратиграфия поселения Давлеканово: по материалам раскопок
Г.Н. Матюшина // Поволжские финны и их соседи в древности и средние века: IV всерос. науч. конф. / отв. ред. В.В. Гришаков. Саранск: Мордов. гос. пед. ин-т., 2016. С. 129-139.

45. Морозов В.В., Ставицкий В.В. К вопросу о стратиграфии поселения Давлеканово (Южное Приуралье) // Евразия в кайнозое. Стратиграфия, палеоэкология, культуры / отв. ред. И.М. Бердников, Е.А. Липнина. Иркутск: Изд-во ИГУ, 2016. Вып. 5. C. $195-200$.

46. Шипилов А.В. Энеолит Икско-Бельского междуречья: автореф. дис. ... канд. ист. наук. Казань, 2012. 19 c.

47. Моргунова Н.Л. Неолит и энеолит юга лесостепи Волго-Уральского междуречья. Оренбург: Оренбург. пед. ин-т, 1995. 222 с.

48. Ставицкий В.В. К вопросу о происхождении гаринско-борской культуры // Археология Восточноевропейской лесостепи. Вып. 2. Т. II / отв. ред. В.В. Ставицкий. Пенза: Пензенский государственный краеведческий музей, 2008. С. 49-57.

49. Моргунова Н.Л., Выборнов А.А., Ковалюх Н.Н., Скрипкин В.В. Хронологическое соотношение энеолитических культур Волго-Уральского региона в свете радиоуглеродного датирования // Российская археология. 2010. № 4. С. 18-27.

50. Моргунова Н.Л. Энеолит Волжско-Уральского междуречья. Оренбург: Изд-во ОГПУ, 2011. 220 с.

51. Моргунова Н.Л., Васильева И.Н., Кулькова М.А., Рослякова Н.В., Салугина Н.П., Турецкий М.А., Файзуллин А.А., Хохлова О.С. Турганикское поселение в Оренбургской области. Оренбург: Издательский центр ОГАУ, 2017. 300 с.

\title{
NOVOILYINSKAYA CULTURE SITES OF THE LOWER KAMA REGION: CURRENT STATE OF THE RESEARCH
}

(C) 2019

\author{
Morozov Viktor Vladimirovich, postgraduate student of Prehistoric Archeology Department \\ Institute of Archaeology named after A.H. Khalikov of Academy of Sciences of Republic of Tatarstan
} (Kazan, Russian Federation)

\begin{abstract}
The paper deals with the analysis of the Novoilyinskaya culture sites existed in the Lower Kama region between the Kama Neolithic culture collapse and the Copper Age cultures with porous (shell tempered) ceramics appearance. The analysis of the ceramic complex of the Novoilyinskaya culture shows its similarity with the comb ornamented pottery of the Kama Neolithic culture according to a number of indicators. A lack of clear data on stratigraphy and spatial distribution of finds as well as a small series of absolute dates do not give a clear idea of the formation time and the development of the Novoilyinskaya culture. Currently available data show that the Samara collar (Ivanovskaya) traditions disappeared until the last quarter of the $5^{\text {th }}$ Millennium cal BC. Specific ceramics of the «Neolithic-type» shape is formed in the Lower Kama region. At the same time the Novoilyinskaya culture ceramics of the Ik and Belaya Rivers interfluve has some features which are the reminiscences of the Levshinskaya stage which are not characteristic for the Middle and Upper Kama region. These features are: thickening on the inner side of the rim; rows of pits and bulges (formed by pits imprinted from the inner side) under the rim; closed forms of the pots and an ornamentation - «stepping comb» impressions. The proximity of the ceramic complexes of the Novoilyinskaya culture sites to the Late Neolithic ceramics of the Kama culture as well as the radiocarbon dates and the absence of the metalworking evidences prove the functioning of the Novoilyinskaya culture sites of the Lower Kama region during the border of the Stone Age and the period of Early Metals. Another important question is - which southern components took part in the formation of the Novoilyinskaya type or influenced it. Researchers of the forest-steppe Copper Age cultures supposed that in the process of forest Copper Age cultures formation - the Garin and Bor cultures as well as the Middle Volga variant of the Volosovo culture - the Tok and even Altata elements took part. In our opinion, the influence of the Tok traditions is already clearly visible on the Novoilyinskaya culture ceramics. This conclusion is supported by the ${ }^{14} \mathrm{C}$ dates which established the synchronicity of the Tok and Novoilyinskaya sites.

Keywords: Novoilyinskaya culture; Tok-type; Neolithic; Copper Age; Lower Kama region; Ik and Belaya Rivers interfluve; forest; forest-steppe; settlement site; ceramics; chamotte; porous (shell tempered) ceramic complexes; cultural diffusion; reminiscences of Levshinskaya stage; typological proximity; multi-component impact.
\end{abstract}

